\title{
Short communication: Red deer (Cervus elaphus) colostrum during its transition to milk
}

\author{
J. A. de la Vara, ${ }^{1}$ M. I. Berruga, ${ }^{1,2}$ M. P. Serrano,,${ }^{2,3,4 *}$ E. L. Cano, ${ }^{5}$ A. García, ${ }^{2,3,4}$ T. Landete-Castillejos,,${ }^{2,3,4}$ \\ L. Gallego, ${ }^{2,3,4}$ A. Argüello, ${ }^{6}$ M. Carmona, ${ }^{7}$ and A. Molina ${ }^{1,2}$ \\ ${ }^{1}$ Food Quality Research Group, Institute for Regional Development (IDR), Universidad de Castilla-La Mancha, Albacete 02071, Spain \\ ${ }^{2}$ Departamento de Ciencia y Tecnología Agroforestal y Genética, Escuela Técnica Superior de Ingenieros Agrónomos y de Montes, \\ Universidad de Castilla-La Mancha, Albacete 02071, Spain \\ ${ }^{3}$ Animal Science Techniques Applied to Wildlife Management Research Group, Instituto de Investigación en Recursos Cinegéticos (IREC), \\ Albacete Section of CSIC-UCLM-JCCM, Universidad de Castilla-La Mancha, Albacete 02071, Spain \\ ${ }^{4}$ Sección de Recursos Cinegéticos y Ganaderos, Institute for Regional Development (IDR), Universidad de Castilla-La Mancha, Albacete 02071, \\ Spain \\ ${ }^{5}$ Quantitative Methods and Socio-Economic Development Group, Institute for Regional Development (IDR), Universidad de Castilla-La Mancha, \\ Albacete 02071, Spain \\ ${ }^{6}$ Department of Animal Science, Universidad de Las Palmas de Gran Canaria, Arucas 35413, Spain \\ ${ }^{7}$ School of Architecture, Engineering and Design, Food Technology Laboratory, Universidad Europea de Madrid, Madrid 28670, Spain
}

\begin{abstract}
We studied changes in chemical composition, somatic cell count, and immunoglobulin G (IgG) and M (IgM) content in red deer (Cervus elaphus) colostrum during the transition to milk at different times after parturition ( $<5 \mathrm{~h}, 24 \mathrm{~h}, 48 \mathrm{~h}, 2 \mathrm{wk}$, and $4 \mathrm{wk})$. The production level was higher at 2 and 4 wk of lactation than during the first day after parturition, with intermediate values at $48 \mathrm{~h}$ postpartum. Fat content did not vary during the study period. However, total protein and casein contents were particularly high in the initial $5 \mathrm{~h}$ after parturition, decreasing to approximately $50 \%$ after $24 \mathrm{~h}$ postpartum. Conversely, lactose concentration was low in the beginning $(<5 \mathrm{~h})$, increasing gradually throughout the study. Similarly, dry matter dropped during the first $24 \mathrm{~h}$ and then remained constant throughout the study. Urea content decreased during the study, showing a slight recovery at 4 wk. Somatic cell count was higher during the first hours after parturition and gradually decreased throughout the study period. The IgG content was higher before $5 \mathrm{~h}$ postpartum than at $24 \mathrm{~h}$ postpartum. After $5 \mathrm{~h}$, the level of IgG decreased progressively until it reached $0.18 \mathrm{mg} / \mathrm{mL}$ at 4 wk of lactation. We observed a similar pattern for IgM content, but it decreased more quickly than IgG and was not detected after 2 wk. In the case of deer, milk should be considered transitional from 24 to $48 \mathrm{~h}$ after parturition, and samples collected after 2 wk can be considered mature milk.
\end{abstract}

Received October 22, 2019.

Accepted January 4, 2020.

*Corresponding author: Martina.Perez@uclm.es
Key words: colostrum, deer, immunoglobulins, milk composition, somatic cells

\section{Short Communication}

As a result of the lack of gamma globulins in newborn ruminants (Hedegaard and Heegaard, 2016), intake of colostrum in the first hours postpartum is crucial. In addition to providing nutritional benefit, colostrum supplies immunity, because it contains several immunoglobulins (Tsioulpas et al., 2007). Colostrum in small ruminants changes its composition and properties to that of mature milk within a few hours or days postpartum (Castro et al., 2011; Sánchez-Macías et al., 2014), and it is important to assess the changes in variables and the timing of this transition. Colostrum transition to milk has been assessed in different ruminant species, and the transition time varies: 5 to $7 \mathrm{~d}$ for cows (Gapper et al., 2007; Georgiev, 2008), 3 to 5 d for goats (Romero et al., 2013; Sánchez-Macías et al., 2014), 6 to 8 d for sheep (Keskin et al., 2007; Pavlíková et al., 2010), and 5 d for buffalo (Abd El -Fattah et al., 2012). Several factors affect the transition, including litter size and lactation number (Argüello et al., 2006; Romero et al., 2013; Ruiz et al., 2015). Although changes in the composition of red deer milk throughout lactation have been well studied (Arman et al., 1974; Landete-Castillejos et al., 2000, 2003, 2005; Serrano et al., 2018), little is known about the composition and immunological properties of colostrum and its transition to milk. One of the reasons for this lack of research might be the difficulty involved in obtaining samples of colostrum or transition milk, even from captive red deer (let alone from hinds in the wild). Arman et al. (1974) studied the composition of 
colostrum samples from red deer and concluded that the complete transition from colostrum to mature milk occurred in no more than $3 \mathrm{~d}$. However, data from this study were limited to 3 hinds milked at 0,15 , and 21 $\mathrm{h}$ postpartum, and without assessing immunoglobulin concentrations. Recent studies have evaluated the technological variables of red deer milk, concluding that this milk is suitable for dairy products (de La Vara et al., 2018). Therefore, it is important to understand the changes occurring in the transition from colostrum to milk, both to comply with food regulations and to avoid the negative effects of colostrum presence in final dairy products. The purpose of this study was to assess the evolution of physicochemical and immunological variables in the transition from colostrum to milk during early lactation in red deer.

For this aim, colostrum and transition to milk samples were collected from each hind from an original Iberian population of red deer (Cervus elaphus: Skog et al., 2009) kept at the experimental farm of University of Castilla-La Mancha (Albacete, Spain) during the calving season in 2013. Colostrum and transition to milk samples were collected by milking according to Landete-Castillejos et al. (2000) within $5 \mathrm{~h}(\mathrm{n}=11)$ and at $24 \mathrm{~h}(\mathrm{n}=11), 48 \mathrm{~h}(\mathrm{n}=8), 2 \mathrm{wk}(\mathrm{n}=14)$, and $4 \mathrm{wk}(\mathrm{n}=14)$ after parturition. The differences in the number of replicates used in each case were due to the impossibility of accessing all animals at each sampling, because the experimental hinds were reared in semicaptivity during the study.

For ethical reasons, because deer are wild and because of the semi-free status of hinds in the rather large enclosures at the experimental farm, the authors decided not to collect colostrum immediately postpartum. Instead, milking was conducted at 2 to $5 \mathrm{~h}$ postpartum, creating the first set of samples as milked in less than $5 \mathrm{~h}$ postpartum. Yield was measured using a graduated cylinder at the handling premises.

Each sample was divided into 2 aliquots of $100 \mathrm{~mL}$. From the 2 aliquots, the first was stored at $4^{\circ} \mathrm{C}$ until analysis for composition and SCC, and the second was immediately frozen and stored at $-70^{\circ} \mathrm{C}$ for assessment of immunological variables. Gross composition (fat, total protein, casein, lactose, DM, and urea) of the colostrum and transition milk samples was determined at the Official Regional Dairy Laboratory (LILCAM, Toledo, Spain) using an automated infrared method with a MilkoScan FT120 milk analyzer (Foss Electric, Hillerød, Denmark) subjected to quality controls and inter-comparative trials. The mean values \pm standard deviation for fat, total protein, casein, lactose, and DM were expressed as percentage, and urea was expressed in milligrams per $100 \mathrm{~mL}$. The SCC was calculated (as $\log$ cells/mL) by flow cytometry using Fossomatic FC equipment (Foss Electric). Just before immunoglobulin analysis, the frozen material was thawed at $4{ }^{\circ} \mathrm{C}$ and the lipid fraction was removed by centrifugation at 10,000 $\times g$ for $10 \mathrm{~min}$ at $4^{\circ} \mathrm{C}$. Quantification of $\operatorname{IgG}$ and $\operatorname{IgM}$ in colostrum was performed using goat ELISA kits (Bethyl Laboratories, Montgomery, TX) according to the method of Moreno-Indias et al. (2012).

For each parameter measured in the samples, we fitted a repeated-measures model using $\mathrm{R}$ statistical software and programming language (R Core Team, 2018). In particular, we relied on the "nlme" package by Pinheiro et al. (2018), which uses the expectation maximization algorithm described by Laird and Ware (1982). This algorithm can handle unbalanced designs and missing values, as was the case in this study, where it was not possible to get samples from all animals at each time point. Thus, we fitted a linear mixed effect model to estimate the variance of the random effect (individual) and the means within the fixed effect (time). Then, for variables whose models were significant according to ANOVA, we made pairwise comparisons using the "multcomp" package (Hothorn et al., 2008), selecting the Tukey method for linear mixed effects. We analyzed the model residuals, confirming normality for most of the variables. For variables whose normality could not be confirmed, a log-transformed fitting of the model led to the same conclusions (details omitted for the sake of clarity).

We observed no differences in production level between 5 and $48 \mathrm{~h}$ postpartum, but after that production gradually increased until 2 and $4 \mathrm{wk}$; values at $48 \mathrm{~h}$ were intermediate $(P=0.001$; Table 1$)$. Arman et al. (1974) observed a similar evolution when calculating the colostrum production of 3 hinds milked at 0,15 , and $21 \mathrm{~h}$. Several studies in goats have reported an inverted bell-shaped curve of production, with a higher colostrum volume immediately postpartum that decreased in the first hours and started to recover after 24 to 48 h (Romero et al., 2013; Sánchez-Macías et al., 2014). Similarly, a quadratic behavior has been described for the volume produced within 4 to $5 \mathrm{~d}$ postpartum in sheep (Alves et al., 2015). The different milking time intervals in the studies above, together with the difficulty of obtaining samples from red deer hinds in the first $2 \mathrm{~h}$ after calving, could explain the differences in patterns reported by other authors compared with those observed in the current study. In our 20-yr experience observing red deer, we have found that calves suckle about 4 to 5 times in the first hours (data not shown), so we may have missed valuable information from the very early colostrum samples. However, for ethical reasons we could not isolate the mothers from the calves in the first $5 \mathrm{~h}$ postpartum to standardize the colostrum stored in the mammary glands, so the 
Table 1. Effects of time after delivery on production, composition and SCC of deer colostrum, 2013 (mean \pm SD)

\begin{tabular}{|c|c|c|c|c|c|c|}
\hline \multirow[b]{2}{*}{ Item } & \multicolumn{5}{|c|}{ Time postpartum } & \multirow[b]{2}{*}{$P$-value } \\
\hline & $<5 \mathrm{~h}(\mathrm{n}=11)$ & $24 \mathrm{~h}(\mathrm{n}=11)$ & $48 \mathrm{~h}(\mathrm{n}=8)$ & $2 \mathrm{wk}(\mathrm{n}=14)$ & 4 wk $(\mathrm{n}=14)$ & \\
\hline Total protein, $\%$ & $13.21 \pm 2.92^{\mathrm{a}}$ & $7.00 \pm 0.47^{\mathrm{b}}$ & $7.01 \pm 0.69^{\mathrm{b}}$ & $6.60 \pm 0.33^{\mathrm{b}}$ & $6.79 \pm 0.49^{\mathrm{b}}$ & $<0.001$ \\
\hline Casein, \% & $9.11 \pm 2.22^{\mathrm{a}}$ & $4.51 \pm 0.41^{\mathrm{b}}$ & $4.56 \pm 0.54^{\mathrm{b}}$ & $4.45 \pm 0.24^{\mathrm{b}}$ & $4.45 \pm 0.34^{\mathrm{b}}$ & $<0.001$ \\
\hline Casein/total protein, $\%$ & $68.6 \pm 2.21^{\mathrm{a}}$ & $64.35 \pm 1.79^{\mathrm{b}}$ & $64.98 \pm 1.74^{\mathrm{b}}$ & $67.38 \pm 1.45^{\mathrm{a}}$ & $65.63 \pm 2.17^{\mathrm{b}}$ & $<0.001$ \\
\hline Urea, mg/100 mL & $702.5 \pm 65.6^{\mathrm{a}}$ & $591.2 \pm 54.7^{\mathrm{b}}$ & $556.5 \pm 43.7^{\mathrm{b}}$ & $563.4 \pm 49.2^{\mathrm{b}}$ & $660.3 \pm 73.3^{\mathrm{ac}}$ & $<0.001$ \\
\hline $\mathrm{SCC}, \log$ cells $/ \mathrm{mL}$ & $6.03 \pm 0.29^{\mathrm{a}}$ & $5.16 \pm 0.28^{\mathrm{bc}}$ & $5.51 \pm 0.69^{\mathrm{b}}$ & $5.15 \pm 0.50^{\mathrm{bc}}$ & $4.90 \pm 0.60^{\mathrm{c}}$ & $<0.001$ \\
\hline
\end{tabular}

${ }^{\mathrm{a}-\mathrm{d}}$ Means within a row with different superscripts differed $(P<0.05)$.

calves could have suckled several times before the first milking. We avoided such an isolation protocol because it was likely to result in the rejection of the calf by the mother and, therefore, could have resulted in the death of several calves.

Our results indicated substantial changes in the chemical composition of samples from the first hours postpartum through the early lactation period. Fat concentration at 2 and 4 wk was similar to the values reported in previous studies (Landete-Castillejos et al., 2001; Serrano et al., 2018). However, the fat content was similar throughout the experimental period $(P=$ 0.499). Arman et al. (1974) characterized the colostrum of 3 hinds at different time intervals during the first $2 \mathrm{~d}$ postpartum and found slightly higher fat content in the first hours postpartum (about 11\%), but after $24 \mathrm{~h}$ fat levels were lower than $8 \%$, similar to values observed in the current study. Fat content seems to be more stable in the transition from colostrum to milk in red deer than in other ruminant species. Indeed, fat evolution in the transitional period from colostrum to milk has been found to follow a different pattern depending on the species (Argüello et al., 2006; Keskin et al., 2007; Romero et al., 2013) or even the breed (Pattinson and Thomas, 2004; Rachman et al., 2015). For colostrum from sheep, goats, or cows, the decrease in fat content during successive milkings postpartum was more pronounced, with a 30 to $50 \%$ decrease in similar periods (Romero et al., 2013; Sánchez-Macías et al., 2014; Alves et al., 2015; McGrath et al., 2016).

Total protein and casein contents were particularly high in the initial $5 \mathrm{~h}$ after parturition, decreasing to approximately $50 \%$ during the $24 \mathrm{~h}$ thereafter $(P<$ 0.001). Then, total protein content decreased slightly and tended to show a similar composition to that reported by our research group for this species (and the same herd) in mature milk (Landete-Castillejos et al., 2000; Serrano et al., 2018). The proportion of casein in relation to total protein was higher in samples obtained in the first $5 \mathrm{~h}$ postpartum than in samples from 24 $\mathrm{h}$ postpartum. Arman et al. (1974) found a ratio of casein to total protein similar to that observed in the current study at 24 and $48 \mathrm{~h}$ postpartum. However, the ratio between casein and total protein observed by Arman et al. (1974) in the colostrum from a hind immediately postpartum was lower than that observed in our study for colostrum obtained during the first 5 $\mathrm{h}$ postpartum. Studies in other species reported that the protein content of colostrum just after calving is almost twice as high as that after $24 \mathrm{~h}$ (Romero et al., 2013; Sánchez-Macías et al., 2014; Alves et al., 2015; McGrath et al., 2016). However, these authors did not specifically study the evolution of casein during the first days postpartum.

Data about casein content in deer colostrum are very scarce. However, it is possible that deer colostrum obtained during the first hours after delivery has a higher casein/protein proportion than colostrum from other ruminants. For example, Gajdůšek et al. (2001) found a lower proportion of casein in the total protein content during the first hours postpartum $(2$ and $24 \mathrm{~h}$ ) in goats compared with that found in red deer at 5 and $24 \mathrm{~h}$ postpartum in the current study. Discrepancies observed for the casein and protein proportions of colostrum between authors might be due to differences in the diets consumed by the animals in each study (Pecka-Kiełb et al., 2018). However, it seems more likely that deer colostrum produced during the first hours postpartum might be different in its proportion of casein because of biological differences between species. In fact, the colostrum of various species varies widely in the amounts and proportions of its principal constituents because of differences in physiology and digestion (Bernabucci et al., 2013). Interspecies variations reflect, in part, different adaptive strategies to environmental conditions and selective pressures of various species during evolution.

Lactose concentration was low at the beginning of lactation, increasing throughout the study $(P<0.001)$. 
This finding was in agreement with the findings of several authors in other ruminants (Romero et al., 2013; Sánchez-Macías et al., 2014; Alves et al., 2015; McGrath et al., 2016). Lactose production is directly related to water influx, and the initial low concentration of this disaccharide could explain the lower volumes observed at the first sampling times (Ontsouka et al., 2003; McGrath et al., 2016). The content of this carbohydrate was lower than the content reported by Arman et al. (1974) during the first $24 \mathrm{~h}$. These authors did not find differences in lactose during the period of lactation studied ( 0 to $260 \mathrm{~d}$ postpartum).

Dry matter decreased during the first $24 \mathrm{~h}$ and then remained constant throughout the study period $(P<$ 0.001). Similar results have been described in red deer for colostrum (Arman et al., 1974) and for milk during the initial period of lactation (Serrano et al., 2018). A comparable evolution of DM during the earliest lactation days has also been described for goats (Romero et al., 2013; Sánchez-Macías et al., 2014), sheep (Alves et al., 2015), and cows (McGrath et al., 2016).

Urea content decreased during the period of study, showing a slight recovery in the fourth week of lactation $(P<0.001)$. We found no studies that reported on urea content in red deer colostrum or milk. However, a similar pattern has been described for the urea content of goat colostrum (Gajdůšek et al., 2001; Ruiz et al., 2015). Urea concentration is related to the feed consumed. However, the feed did not change during the milking time in the current study. Therefore, we can assume that changes in urea content were not associated with changes in diet. A variable content of nonprotein nitrogen was reported by Arman et al. (1974) in individual samples, with higher concentrations observed at initial times during lactation.

In contrast, SCC was higher during the first hours after parturition and gradually decreased $(P<0.001)$ until reaching values similar to those reported for red deer milk (Kurki et al., 2004; de La Vara et al., 2018). We found no studies reporting on the SCC of red deer colostrum. However, the higher content of SCC observed in red deer colostrum than in milk in the current study was in accordance with findings for cows (Wall et al., 2015) and goats (Ontsouka et al., 2003; Romero et al.,
2013; Sánchez-Macías et al., 2014). The engorgement of the udder during advanced pregnancy often results in very high-level stress on the tissue, which may be responsible for the elevated SCC and neutrophil counts during the first day of colostrum production for Murrah buffalo (Kalyan et al., 2010). Frequent emptying of the udder (Dang and Anand, 2007) returns SCC gradually to normal values as the stress on the udder tissue decreases.

Deer colostrum during the first $5 \mathrm{~h}$ postpartum was richer in immunity molecules (IgG and $\operatorname{IgM}$ ) than successive samples during early lactation $(P<0.001$; Table 2). Mean IgG values in deer milked up to $5 \mathrm{~h}$ postpartum were more than 4 times higher than values observed at $24 \mathrm{~h}$. After that, IgG levels decreased until they reached $0.18 \mathrm{mg} / \mathrm{mL}$ at $4 \mathrm{wk}$. We observed a similar pattern for IgM content. However, IgM decreased faster than IgG and was not detected after 2 wk of lactation. We found no reports on immunoglobulin content over time in red deer colostrum and transition to milk. The decrease in immunoglobulins after delivery agrees with results for cows (Zhao et al., 2010) and goats (Romero et al., 2013; Sánchez-Macías et al., 2014). In fact, these authors concluded that IgG was 4 to 10 times lower in the initial $48 \mathrm{~h}$ postpartum. It is worth mentioning that, compared with available data at 24 and 48 $\mathrm{h}$ postpartum, the IgG and IgM content found in the current study were much lower than those observed for cows (Zhao et al., 2010) and goats (Romero et al., 2013; Sánchez-Macías et al., 2014) at the same time points.

According to the patterns observed for immunoglobulins and the other variables analyzed, we suggest that from 24 to $48 \mathrm{~h}$ after parturition, secretions should be considered transitional milk, because the immunoglobulin content was too low for colostrum but too high for milk. Samples collected after 2 wk can be considered to be milk: all components fell within the normal ranges described in the literature for deer milk. Arman et al. (1974) reported a rapid transition from colostrum to mature milk in less than $3 \mathrm{~d}$. In general, the complete transition has been fixed between 3 and 5 d for other ruminants (Abd El -Fattah et al., 2012; Romero et al., 2013; Sánchez-Macías et al., 2014; Chen et al., 2018). These results could be because of the need

Table 2. Effects of time after delivery on IgG and IgM content of deer colostrum, 2013 (mean \pm SD)

\begin{tabular}{lcccccc}
\hline & \multicolumn{4}{c}{ Time postpartum } & & \\
\cline { 2 - 5 } Item & $<5 \mathrm{~h}\left(\mathrm{n}_{\mathrm{IgG}}=8 ; \mathrm{n}_{\mathrm{IgM}}=11\right)$ & $24 \mathrm{~h}(\mathrm{n}=11)$ & $48 \mathrm{~h}(\mathrm{n}=8)$ & 2 wk $(\mathrm{n}=14)$ & 4 wk $(\mathrm{n}=14)$ & $P$-value \\
\hline $\mathrm{IgG}, \mathrm{mg} / \mathrm{mL}$ & $8.73 \pm 3.92^{\mathrm{a}}$ & $1.81 \pm 1.66^{\mathrm{b}}$ & $1.76 \pm 1.15^{\mathrm{b}}$ & $0.24 \pm 0.09^{\mathrm{b}}$ & $0.18 \pm 0.09^{\mathrm{b}}$ & $<0.001$ \\
$\mathrm{IgM}, \mathrm{mg} / \mathrm{mL}$ & $0.049 \pm 0.017^{\mathrm{a}}$ & $0.013 \pm 0.008^{\mathrm{b}}$ & $0.004 \pm 0.007^{\mathrm{c}}$ & $\mathrm{ND}^{1}$ & $\mathrm{ND}^{1}$ & $<0.001$ \\
\hline
\end{tabular}

${ }^{\mathrm{a}-\mathrm{c}}$ Means within a row with different superscripts differed $(P<0.05)$.

${ }^{1}$ Not detected. 
for wild animals to transmit immunity to offspring as quickly as possible. However, more studies are needed to characterize the composition of deer colostrum in the first days after delivery.

\section{ACKNOWLEDGMENTS}

This work was supported by the Ministerio de Economía y Competitividad and the European Union Fund for Regional Development [INCYDEN Project RTC-2016-5327-2], and project [MTM2017-86875-C31-R AEI/ FEDER, UE]. M. Carmona is grateful for the Ramón y Cajal Fellowships RyC-2014-16307 by the Spanish Ministry of Science, Innovation and Universities. Finally, the authors thank Ralph Wilk (native autonomous reviewer, Valencia, Spain) for the language review. The authors have not stated any conflicts of interest.

\section{REFERENCES}

Abd El-Fattah, A. M., F. H. R. Abd Rabo, S. M. El-Dieb, and H. A. El-Kashef. 2012. Changes in composition of colostrum of Egyptian buffaloes and Holstein cows. BMC Vet. Res. 8:19. https://doi.org/ 10.1186/1746-6148-8-19.

Alves, A. C., N. G. Alves, I. J. Ascari, F. B. Junqueira, A. S. Coutinho, R. R. Lima, J. R. O. Pérez, S. O. De Paula, I. F. FurushoGarcia, and L. R. Abreu. 2015. Colostrum composition of Santa Inês sheep and passive transfer of immunity to lambs. J. Dairy Sci. 98:3706-3716. https://doi.org/10.3168/jds.2014-7992.

Argüello, A., N. Castro, S. Álvarez, and J. Capote. 2006. Effects of the number of lactations and litter size on chemical composition and physical characteristics of goat colostrum. Small Rumin. Res. 64:53-59. https://doi.org/10.1016/j.smallrumres.2005.03.016.

Arman, P., R. N. Kay, E. D. Goodall, and G. A. M. Sharman. 1974. The composition and yield of milk from captive red deer (Cervus elaphus L.). J. Reprod. Fertil. 37:67-84. https://doi.org/10.1530/ jrf.0.0370067.

Bernabucci, U., L. Basiricò, and P. Morera. 2013. Impact of hot environment on colostrum and milk composition. Cell. Mol. Biol. (Noisy-le-Grand) 59:67-83. https://doi.org/10.1170/T948.

Castro, N., J. Capote, R. M. Bruckmaier, and A. Argüello. 2011. Management effects on colostrogenesis in small ruminants: A review. J. Appl. Anim. Res. 39:85-93. https://doi.org/10.1080/09712119 .2011 .581625 .

Chen, D., X. Zhao, X. Li, J. Wang, and C. Wang. 2018. Milk compositional changes of Laoshan goat milk from partum up to 261 days postpartum. Anim. Sci. J. 89:1355-1363. https://doi.org/10 $.1111 /$ asj.13062.

Dang, A. K., and S. K. Anand. 2007. Effect of milking systems on the milk somatic cell counts and composition. Livest. Res. Rural Dev. 19:1-9.

de La Vara, J. A., M. I. Berruga, J. Cappelli, T. Landete-Castillejos, M. Carmona, L. Gallego, and A. Molina. 2018. Some aspects of the ethanol stability of red deer milk (Cervus elaphus hispanicus): A comparison with other dairy species. Int. Dairy J. 86:103-109. https://doi.org/10.1016/j.idairyj.2018.07.006.

Gajdůšek, S., S. Kráčmar, P. Jelínek, and J. Kuchtík. 2001. Changes in protein content and correlations between contents of amino acids of goat's colostrum during the first 72 hours after parturition. Czech J. Anim. Sci. 46:11-16.

Gapper, L. W., D. E. J. Copestake, D. E. Otter, and H. E. Indyk. 2007. Analysis of bovine immunoglobulin G in milk, colostrum and dietary supplements: A review. Anal. Bioanal. Chem. 389:93-109. https://doi.org/10.1007/s00216-007-1391-z.
Georgiev, I. P. 2008. Differences in chemical composition between cow colostrum and milk. Bulg. J. Vet. Med. 11:3-12.

Hedegaard, C. J., and P. M. H. Heegaard. 2016. Passive immunisation, an old idea revisited: Basic principles and application to modern animal production systems. Vet. Immunol. Immunopathol. 174:5063. https://doi.org/10.1016/j.vetimm.2016.04.007.

Hothorn, T., F. Bretz, and P. Westfall. 2008. Simultaneous inference in general parametric models. Biom. J. 50:346-363. https://doi.org/ 10.1002/bimj. 200810425.

Kalyan, D., J. Mukherjee, A. K. Dang, C. Singh, and S. Prasad. 2010. Studies on differential leukocyte counts in the colostrum of Murrah Buffalo. Rev. Vet. 21:603-605.

Keskin, M., Z. Güler, S. Gul, and O. Biçer. 2007. Changes in gross chemical compositions of ewe and goat colostrum during ten days postpartum. J. Appl. Anim. Res. 32:25-28. https://doi.org/10 .1080/09712119.2007.9706840.

Kurki, J., A. Pitkälä, and M. Nieminen. 2004. The hygienic quality of raw reindeer milk. Rangifer 24:67-70. https://doi.org/10.7557/ 2.24.2.302.

Laird, N. M., and J. H. Ware. 1982. Random-effects models for longitudinal data. Biometrics 38:963-974. https://doi.org/10.2307/ 2529876 .

Landete-Castillejos, T., A. García, and L. Gallego. 2001. Calf growth in captive Iberian red deer (Cervus elaphus hispanicus): Effects of birth date and hind milk production and composition. J. Anim. Sci. 79:1085-1092. https://doi.org/10.2527/2001.7951085x.

Landete-Castillejos, T., A. García, J. A. Gómez, and L. Gallego. 2003. Subspecies and body size allometry affect milk production and composition, and calf growth, in red deer: Comparison of Cervus elaphus hispanicus and Cervus elaphus scoticus. Physiol. Biochem. Zool. 76:594-602. https://doi.org/10.1086/375660.

Landete-Castillejos, T., A. García, F. R. López-Serrano, and L. Gallego. 2005. Maternal quality and differences in milk production and composition for male and female Iberian red deer calves (Cervus elaphus hispanicus). Behav. Ecol. Sociobiol. 57:267-274. https: //doi.org/10.1007/s00265-004-0848-8.

Landete-Castillejos, T., A. García, P. Molina, H. Vergara, J. Garde, and L. Gallego. 2000. Milk production and composition in captive Iberian red deer (Cervus Elaphus Hispanicus): Effect of birth date. J. Anim. Sci. 78:2771-2777. https://doi.org/10.2527/2000 $.78112771 \mathrm{x}$

McGrath, B. A., P. F. Fox, P. L. H. McSweeney, and A. L. Kelly. 2016. Composition and properties of bovine colostrum: A review. Dairy Sci. Technol. 96:133-158. https://doi.org/10.1007/s13594 $-015-0258-x$.

Moreno-Indias, I., D. Sánchez-Macías, N. Castro, A. Morales-de la Nuez, L. E. Hernández-Castellano, J. Capote, and A. Argüello. 2012. Chemical composition and immune status of dairy goat colostrum fractions during the first $10 \mathrm{~h}$ after partum. Small Rumin. Res. 103:220-224. https://doi.org/10.1016/j.smallrumres.2011.09 .015 .

Ontsouka, C. E., R. M. Bruckmaier, and J. W. Blum. 2003. Fractionized milk composition during removal of colostrum and mature milk. J. Dairy Sci. 86:2005-2011. https://doi.org/10.3168/jds .S0022-0302(03)73789-8.

Pattinson, S. E., and E. W. Thomas. 2004. The effect of sire breed on colostrum production of crossbred ewes. Livest. Prod. Sci. 86:4753. https://doi.org/10.1016/S0301-6226(03)00169-6.

Pavlíková, E., J. Blaško, R. Górová, G. Addová, R. Kubinec, M. Margetín, and L. Soják. 2010. Variation in fatty acid composition of ewes' colostrum and mature milk fat. Int. Dairy J. 20:637-641. https://doi.org/10.1016/j.idairyj.2010.02.008.

Pecka-Kiełb, E., A. Zachwieja, E. Wojtas, and W. Zawadzki. 2018. Influence of nutrition on the quality of colostrum and milk of ruminants. Mljekarstvo 68:169-181. https://doi.org/10.15567/ mljekarstvo.2018.0302.

Pinheiro, J., D. M. Bates, and R Core Team. 2018. Nlme: linear and nonlinear mixed effects models. Accessed Jan. 28, 2020. https:// cran.r-project.org $/$ package $=$ nlme. 
R Core Team. 2018. R: A language and environment for statistical computing. Vienna, Austria: R Foundation for Statistical Computing. Accessed Jan. 28, 2020. https://www.R-project.org/.

Rachman, A. B., R. R. A. Maheswari, and M. S. Bachroem. 2015. Composition and isolation of lactoferrin from colostrum and milk of various goat breeds. Procedia Food Sci. 3:200-210. https://doi .org/10.1016/j.profoo.2015.01.022.

Romero, T., M. C. Beltrán, M. Rodríguez, A. Martí De Olives, and M. P. Molina. 2013. Short communication: Goat colostrum quality: Litter size and lactation number effects. J. Dairy Sci. 96:75267531. https://doi.org/10.3168/jds.2013-6900.

Ruiz, P., S. Seseña, I. Rieiro, and M. L. Palop. 2015. Effect of postpartum time and season on the physicochemical characteristics of Murciano-Granadina goat colostrum. Int. J. Dairy Technol. 68:8896. https://doi.org/10.1111/1471-0307.12163.

Sánchez-Macías, D., I. Moreno-Indias, N. Castro, A. Morales-de la Nuez, and A. Argüello. 2014. From goat colostrum to milk: Physical, chemical, and immune evolution from partum to 90 days postpartum. J. Dairy Sci. 97:10-16. https://doi.org/10.3168/jds.2013 $-6811$.

Serrano, M. P., P. Gambín, T. Landete-Castillejos, A. García, J. Cappelli, F. J. Pérez-Barbería, J. A. Gómez, and L. Gallego. 2018.
Effects of Mn supplementation in late-gestating and lactating red deer (Cervus elaphus hispanicus) on milk production, milk composition, and calf growth. J. Anim. Sci. 96:2038-2049. https://doi org $/ 10.1093 /$ jas $/$ sky087.

Skog, A., F. E. Zachos, E. K. Rueness, P. G. D. Feulner, A. Mysterud, R. Langvatn, R. Lorenzini, S. S. Hmwe, I. Lehoczky, G. B. Hartl N. C. Stenseth, and K. S. Jakobsen. 2009. Phylogeography of red deer (Cervus elaphus) in Europe. J. Biogeogr. 36:66-77. https:// doi.org/10.1111/j.1365-2699.2008.01986.x.

Tsioulpas, A., M. J. Lewis, and A. S. Grandison. 2007. Effect on minerals on casein micelle stability of cows'milk. J. Dairy Res. 74:167173. https://doi.org/10.1017/S0022029906002330.

Wall, S. K., J. J. Gross, E. C. Kessler, K. Villez, and R. M. Bruckmaier. 2015. Blood-derived proteins in milk at start of lactation: Indicators of active or passive transfer. J. Dairy Sci. 98:7748-7756. https://doi.org/10.3168/jds.2015-9440.

Zhao, S., C. Zhang, J. Wang, G. Liu, D. Bu, J. Cheng, and L. Zhou. 2010. Variations of immunoglobulins in colostrum and immune milk as affected by antigen releasing devices. Asian-Australas. J. Anim. Sci. 23:1184-1189. https://doi.org/10.5713/ajas.2010 .90521 